\title{
Van Kalesi Analıkız Yapısı: İşlev ve Kronolojisine Dair Bir Değerlendirme
}

\section{Tushpa/Van Fortress Analıkız Structure: An Evaluation of Function and Chronology}

\author{
Bülent Genç ${ }^{1}$ (), Erkan Konyar² (i]
}

1Sorumlu yazar/Corresponding author: Bülent Genç (Dr. Öğr. Üyesi),

Mardin Artuklu Üniversitesi, Edebiyat Fakültesi, Arkeoloji Bölümü, Mardin, Türkiye

E-mail: bulendgenc@gmail.com

Orcid ID: 0000-0001-9328-1339

2Erkan Konyar (Doç. Dr.), İstanbul Üniversitesi, Edebiyat Fakültesi, Eskiçağ Tarihi Anabilim Dalı, Istanbul, Türkiye

E-mail: konyar@istanbul.edu.tr

Orcid ID: 0000-0002-1256-5960

Başvuru/Submitted: 16.12 .2019 Kabul/Accepted: 17.12.2019

Atıf/Citation: Genc, B., Konyar, E. (2019). Van kalesi analıkız yapısı: Işlev ve kronolojisine dair bir değerlendirme. Anadolu Araştırmaları-Anatolian Research, 22, 1-23.

https://doi.org/10.26650/anar.2019.22.660245

\section{öz}

Van Kalesi'nin kuzeydoğu yamaçlarında, ova düzeyine yakın bir yükseltide Analıkız veya Hazine Kapısı olarak adlandırılan kaya anıtı yer almaktadır. Anıt ana kayaya işlenmiş bir platform ve gerisinde yine ana kayaya açılmış iki adet anıtsal nişten oluşur. Marr ve Orbeli'nin 1916 yılında gerçekleştirdikleri kazılardan bu yana Analıkız alanının işlevi, sitadelle ilişkisi, krallık açısından önemi, inşa evreleri ve mimari tasarımı hakkında ayrıntılı bir değerlendirme yapılmamıştır. Literatürde bu alan genel olarak Açık Hava Kutsal Alanı olarak tanımlanmıştır. Lehmann-Haup'tun 1898 'lerde alanın kuzeyinde yer alan drenaj kanallarını kurban kanalı olarak tanımlaması açık hava kutsal alanı tanımını yerleştirmiş sonraki çalışmalara referans olmuştur. Bu çalışmamızda alanla ilgili literatür ve hikayeleri ve kazı sonuçlarını tekrar değerlendirerek yeniden tanımlamaya çalışıımıştır. Minua ile başlamış olması muhtemel inşa faaliyetlerinin I. Argişti ve II. Sarduri ile devam ettiği yönündeki tespitler, bu alanın yapım evreleri de göz önüne alınarak değerlendirilmiştir. Analıkız yapısının aslında açık hava kutsal alanı olmayabileceği, krallık için sadece başkente özel ünik bir anıtsal birim olabileceği ele alınmıştır. Söz konusu birimin kralların kroniklerinin yazılı olduğu stellerinin toplu olarak bulunduğu bir alan olabileceği ve bütün çevresel özellikleriyle beraber kapalı bir alan olabileceği arkeolojik ve filolojik kanıtlar üzerinden tartışılmıştır.

Anahtar Kelimeler: Van Kalesi, Analıkız, Urartu, Urartu Dini, Tuşpa

\section{ABSTRACT}

On the northeast sides of the Van Fortress, an elevation nearby, stands a rock monument on the plain named Analıkız or also called Hazine Kapısı. The monument consists of a platform engraved into the rock and two monumental niches. Yet ever since the excavations conducted by Marr and Orbeli in 1916, there have been no detailed examinations or evaluations of the functions of the field, the relationship to the citadel, its importance for the kingdom, the levels of construction or architectural design. In literature, this field is generally recognized vas Open Air Sanctuary or the way Lehmann-Haupt defined in 1898. In this study, we attempted to reevaluate and redefine the literature, stories and excavation outcomes. The deductions suggesting construction activities initiating with Minua then continuing with Argishti I and Sarduri II have been made considering the construction levels of the field. The possibilities of Analıkız structure not being an 
open-air sanctuary but rather a monumental site for the kingdom, a field in which the steles with king's chronicles carved onto them are gathered or a closed field with all of its surroundings have been discussed with the aid of archeological and philological proofs.

Keywords: Van Fortress, Analıkız, Urartian, Urartian Religion, Tushpa

\section{EXTENDED ABSTRACT}

On the northeast sides of the Van Citadel, on an elevation nearby, stands a rock monument on the plain named Analıkız. The monument consists of a platform engraved into the rock and two monumental niches opening to a flattened field which is also carved into the main rock.

The east niche is $6.15 \mathrm{~m}$ tall, $2.60 \mathrm{~m}$ wide and $2.15 \mathrm{~m}$ deep. In the middle of the niche is a bed of $147.9 \times 147.30 \mathrm{~cm}$ carved into the main rock and a space for a stele in the middle of that. The west niche is $8.10 \mathrm{~m}$ tall and $2.60 \mathrm{~m}$ wide. In front of this niche can be found a stele base in three pieces with the chronicles of Sarduri II. written on it and a space for a stele in the middle. It was revealed in-situ during the excavations conducted by Marr-Orbelli. Today, it can be found in the Van Museum in several pieces. The apsidal structure of the top piece of the stele sitting on the base has been used as a gathering material in the Surp Bogos Church.

With Marr and Orbeli's excavations in 1916 and later on at K. Lake in 1938, the field has taken on its current appearance. Lehmann-Haunt especially mentions the canal on the north side opening up to the outer regions of the field, leading to a rocky bed. He mentions that these carry the possibility of being canals for the animals carried to the area for sacrificial purposes. Analıkı has been described in many studies as a sanctuary or open-air temple in which religious and sacrificial ceremonies were executed.

Yet through the reevaluation of the location of the Analık1z compartment, several structural features and various inscriptions unearthed in the surrounding areas of Van Fortress, a new perspective concerning the characteristics of the feature has been proven to be necessary. Within this frame the answers to the following questions have been investigated: When was this field enclosed with walls and steles placed in monumental niches built, and as a result of which factors? As the west niche features chronicles of Sarduri II, what did the east niche feature? Could it be that the stele which catches the eye with all four sides inscribed with chronicles of Argishti the First and was copied while in Surp Sahak Church was used in this site? Similarly, could the stele of Minua in Surp Bogos Church be related to the Analikız site in any way?

The Minua inscription in Surp Bogos Church was $140 \mathrm{~cm}$ wide, $61.5 \mathrm{~cm}$ high and currently $46 \mathrm{~cm}$ deep must have a large stele base. On the front and top parts of the base, a 
text is inscribed. Close to the middle part of the top inscription, an offering pot in the form of two integrated circles has been engraved. With the offering pot and the inscription of the side, this base is quite similar to the Gameşvan/Kamişvan stele base. With this data in mind, it can be assumed that the stele base in Surp Bogos was used on the east niche in the Analikız site.

Considering the general structural characteristics of the site, a development process spread into different chronological processes can be deduced. The structural features of the east niche with its frontal area as well as the west niche with its frontal area suggest two different chronological periods. When evaluated with the inscription within, it can be asserted that the east niche and the frontal area was the first to the built. This information may suggest that this site's construction was initiated during the Minua period. Later on, the site expanded eastwards and the existing front was cascaded backward, making way for the west niche during the reign periods of Argishti the First and especially Sarduri II.

The canal which was formerly called a sacrificial canal located on the northwest of the Analıkı site is $30 \mathrm{~m}$ long. This canal is on the outside portion of the walls which were thought to encircle the northern portion of the site. In this case, it should be considered that this canal, defined as a sacrificial canal, could be functioning as a drainage canal for the discharge of the water supply of the citadel.

The traces of wall beds can be most visibly seen across the west niche, on a relatively higher rocky platform. The same beds can be observed on the east of the site and the areas right on top of the niches. Considering the location of these wall beds, this can be thought to be an enclosed area with access from the citadel. The absence of any kind of staircase or any type of transportation resembling a pathway strengthens the relationship of the site with the citadel. 


\section{Van Kalesi Analıkız Yapısı: İşlev ve Kronolojisine Dair Bir Değerlendirme}

Van Sitadeli'nin kuzeydoğu yamaçlarında, üst kısımları apsidal biçimde adeta Urartu stellerinin birer silüeti gibi kaya cephesine işlenmiş iki adet anıtsal niş yer almaktadır ve bu alan günümüzde Analıkız olarak bilinmektedir (Resim 1). Bu anıtsal nişlerin içerisine "dikili taş" olarak tanımlayabileceğimiz biçimde steller yerleştirilmiştir.

Anıtsal nişler içerisinde stellerin bulunduğu Analıkız'ın doğu-batı uzunluğu yaklaşık olarak 51 metredir. Kuzey-güney doğrultusunda ise en geniş kısmı 13.50 m civarındadır. Böylelikle nişlerin önünde ana kaya oyularak oluşturulmuş yaklaşık $450 \mathrm{~m}^{2}$ lik bir alan söz konusudur. Bu alanın kuzeyinde yine ana kaya oyularak/düzleştirilerek oluşturulan cephede iki anıtsal niş açılmıştır (Resim 2-5). Nişlerin açılmış olduğu yüzeyin platformla birleştiği alan boyunca uzanan bir seki yine ana kayaya oyularak oluşturulmuştur. Bu sekilerin derinlikleri 45-5 cm, yükseklikleri ise 45-60 cm arasında değişir. Doğu nişinin doğusunda yine cepheye açılmış yaklaşık $8.60 \mathrm{~m}$ genişliğinde $1.10-1.20 \mathrm{~m}$ arasında değişen yükseklikte ve $45-50 \mathrm{~cm}$ derinliğinde bir oyuk bulunur (Resim 6). Bu türden oyukların işlevi tam olarak bilinememekle birlikte aynı uygulamanın İşpuini-Minua dönemine ait Meher Kapı'da da uygulanmış olduğunu belirtmekte yarar vardır (Resim 7). Doğu nişin önündeki platform aynı seviyede uzanır. Batı nişin karşısındaki alan ise daha yüksek bir platform olarak düzenlenmiştir. Platform boyunca nişe bakan kuzey yönde ve doğu yönde yine bir seki uzanır. Alanın doğusundaki kısa yüzün önünde, platform ile birleştiği alanda da seki uzanır (Resim 8).

Doğudaki niş $6.15 \mathrm{~m}$. yüksekliğinde, $2.60 \mathrm{~m}$. genişliğinde ve $2.15 \mathrm{~m}$. derinliğindedir (Resim 9). Nişin ortasında 145 x $145 \mathrm{~cm}$ ölçülerinde, kare biçimli ana kayaya oyulmuş bir yatak bunun ortasında ise 70 x $45 \mathrm{~cm}$ ölçülerinde ve yaklaşı $25 \mathrm{~cm}$ derinliğinde yine ana kayaya oyulmuş bir stel yuvası bulunur (Resim 5, 10). Ancak stelin kendisine dair in situ bir buluntu yoktur. Bu konunun ayrıntılarına daha sonra değinilecektir.

Batıdaki niş ise $8.10 \mathrm{~m}$. yüksekliğinde ve $2.60 \mathrm{~m}$. genişliğindedir (Resim 11). Bu nişin derinliği zeminde 2.56 metreden başlayarak nişin üst kısmına doğru azalmaktadır. Örneğin zeminden itibaren 2 metre yükseklikten sonra derinlik 2.24 metreye düşmektedir. Böylece batı nişi geriye yani güneye doğru eğimli olarak işlenmiştir. Nişin iç kısmında ana kayaya cepheden 13 satır (CTU I. A 9-3 VII) nişin üstte doğu (sol) yüzünde ise 29 satır çivi yazılı metin işlenmiştir (CTU I.A 9-3 I), (Resim 12, 13). Yazıtta II. Sarduri'nin askeri seferlerinden ve ele geçirdiği ganimetlerden bahsedilir.

Yine nişin önünde orta kısmında bir stel yuvası bulunan stel kaidesi üç parça halinde bulunur (Resim 14). Kare formundaki kaide 1.56x1.54 metre ölçülerindedir. Yüksekliği 109 cm'dir. Bu kaideye üstte stelin oturtulması için açılan yuva 56x45 cm ölçülerinde ve $60 \mathrm{~cm}$ 
derinliğindedir. Kaidenin ön yüzünde yine II. Sarduri’nin sefer yaptığı ülkeler, tehcir edilen nüfus, imar ve inşa faaliyetleri, ganimet türleri, ordu ve teçhizat sayısı gibi çeşitli faaliyetler yazılidır (CTU I. A 9-3, VI), (Resim 15).

Kaideye oturan stelin uzun dikdörtgen parçası dört yönden yazıtlıdır. Yüzyılın başında yine Marr-Orbelli tarafından yapılan kazılarla in situ biçimde ortaya çıkarılmıştır (Resim16). Söz konusu stel parçası Cumhuriyetin ilk yıllarında parçalanmış olup bugün birçok parça halinde Van Müzesi'nde bulunur. Bu yüksek stelin apsidal biçimli en üst parçası olasılıkla Ortaçağ'da düzgün bir şekilde ikiye ayrılarak bir parçası Eski Van şehrindeki Surp Boğos Kilisesi'nde devşirme malzeme olarak kullanılmıştır. Parçalardan biri Cumhuriyet döneminde Van Müzesi'ne taşınmıştır (CTU I. A 9-1,destro). Surp Boğos Kilisesi'nde yapı taşı olarak kullanılmış ve fakat kaçak müdahalelerle açığa çıkarılmış olan diğer parça ise 2010 yılında tarafımızdan gerçekleştirilen bir kazı çalışması ile çıkartılıp Van Müzesi’ne teslim edilmiştir (CTU I. A 9-1,sinistro) (Resim 17).

II. Sarduri kroniklerinin başlangıcı olarak kabul edilen stel üzerindeki yazıtta söz konusu stel NA4pulusi olarak tanımlanmıştır (CTU I: A 9-1 Ro; 2,15). Önünde taş "NA," determinatifi bulunan pulusi sözcügü yazıtın kendisi olmayıp yukarıda sözünü ettiğimiz formdaki steller için kullanılan Urartuca bir tanımdır. Urartu'da pulusiler çoğunlukla baştanrı Haldi’ye adanmıştır. Ayrıca pulusilerin yazıtsız şeklinin de kutsal kabul edildiği ve önlerinde çeşitli dinsel törenler yapıldığı ile ilgili Erzincan/Altıntepe örnekleri elimizde mevcuttur (Özgüç, 1969, s. 28-33). Tam da bu noktada Analıkız Steli önünde de söz konusu ritüellerin uygulandığı söylenebilir. Nitekim Analıkız stelinin başlangıç yazıtında kurban kesilmesi ile ilgili ifadeler geçmektedir. Yazıtın devamında steli korumaya dönük bir beddua metni ve akabinde kroniklerin ana temasını oluşturan II. Sarduri'nin askeri seferleri anlatılır.

Analıkız Yapı'sında bilimsel nitelikte ilk çalışmaların 19. yüzyılın ilk yarısında başladığını söyleyebiliriz. Alman şarkiyatçısı olan Schulz, 1826'da Kaledeki Urartu yapılarının ayrıntılı tanımını yapmış ve Urartu çivi yazılı kitabelerinin kopyalarını çıkarmıştır. Analıkız kitabelerini de kopyalayan Schulz'un "Khazane Kapoussi”, Hazine Kapısi/Analıkız ile ilgili anlattı̆̆ hikaye oldukça ilginçtir (Schulz, 1840, s. 290-292). 1849 yılında ise Austen Henry Layard Van'a gelerek Hazine Kapısı/Analıkız'da kısa süreli bir kazıda bulunur (Layard, 1853, s. 398-399). Layard Schulz'a atıfta bulunarak ilgili hikayeyi; Khazana Kapousi” veya Hazine Kapısı olarak adlandırılan bu mağara veya oyuğun Hristiyan ve Müslümanlarca kutsal bir alan olarak tanımlandığını, inanışa göre, bu nişlerin altında alev saçan kılıçlarıyla donanmış cinler tarafindan korunan demir bir kapı bulunduğunu, cinlerin koruduğu bu demir kapının her çeşit zenginlikle dolu çok büyük bir salonun girişini kapadığını ve bu ana kapının sadece yazıtta yer alan büyülü sözlerle açıldığını ve geceleri bir yılan tarafindan korunduğunu anlatır. Bu yılan şafakla birlikte mağara civarındaki bir deliğin içine doğru çekilmektedir (Schulz, 1840, s. 290-292; Layard, 1853, s. 398). Aslında Schulz ve Layard, 
19. yüzyılın ikinci yarısından itibaren halkın bu alanı nasıl tanımladığını, inanışa göre nasıl adlandırdığını ve kutsallaştırdığını söz konusu mitoloji üzerinden aktarmaktadır. Hazine Kapısı veya Analıkız olarak adlandırılan bu alanla ilgili inanış biçimi pek değişmemiş ve bu düşünce biçimi farklı bir inanç ve kutsallıkla günümüze kadar ulaşmıştır¹.

Alman Eskiçağ tarihçisi Lehmann-Haupt 1898 yılında Van Gölü Havzası'nda çeşitli araştırmalarda bulunur. Van Kalesi'ne uğrayan Lehmann-Haupt Analıkız Yapısı'nı “Chazineh-kapyssy-Schatztor" olarak tanımlar. Yine Schulz ve Layard'ın anlattığı hikâyeye benzer şekilde bu alanda hazinenin gömülü olduğuna inanıldığından bahsetmektedir. Özellikle alanın dışına doğru kuzey yamaçta kayalık yatağa açılan kanaldan bahseder (Resim 18). İki kola ayrılan bu kanallardan birinin kuzeydoğuya, diğerinin ise doğuya doğru uzandığını belirtir. Lehmann-Haupt bu kanalın bu alana getirilen kurbanlar için kurban kanalı olabileceğini vurgular (Lehmann-Haupt, 1926, s. 29-30). Kendisinin bu değerlendirmesinin daha sonraki dönemde alanın işlevine dair yapılan değerlendirmelerde belirleyici olduğu anlaşılmaktadır. Analıkız daha sonraki birçok araştırmada kutsal alan veya içinde dinsel tören ve kurban sunularının yapıldığı açık hava tapınağı olarak tanımlanmıştır. (Erzen, 1978a, s. 7; Tarhan, 1994, s. 28-31; Çilingiroğlu, 1998, s. 233-234; Tarhan, 2011, s. 320; Kroll, Gruber, Hellwag, Roaf ve Zimansky, 2012, s.16; Korfmann, 1977, s. 184; Salvini, 2006, s. 72, 158; Çilingiroğlu, 2011, s. 194-195).

1916 yılında Marrve Orbeli'nin bu alanda nişleri ve stelleri hedef alan kazılara başlamasıyla alanın kimliği daha da netleşmeye başlamıştır. Marr ve Orbeli'nin çalışmalarında her iki niş ve önlerindeki alanın bir kısmı açılmıştır (Resim 16). Nişlerden birine bitişik şekilde inşa edilmiş kuzeye doğru devam eden ve köşe yaparak doğuya dönen bir duvar ortaya çıkarılmıştır (Marr ve Orbeli, 1922, Pl. XV, XVI).

Marr ve Orbeli'nin kazısından sonra bu kez Kirsopp Lake² 30 Mayıs 1938 yılında Hazine Kapısı/Analıkız'da tekrar çalışmaya başlamıştır ve alanın tümü temizlenerek açığa çıkarılmıştır (Resim 19). Büyük nişin doğusundaki ve nişlerin arasındaki yıkıntıları kaldırarak işe başlayan Lake, batıya doğru kaya ve toprak yığınıyla kaplı daha önce dokunulmamış bir bölümden bahsetmektedir. Lake, çok sayıda büyük taşların bulunduğu bu bölüme taşların batı uçtaki bir yapıdan veya üstteki bir yapıdan düştüğünü belirtmektedir. Özellikle batı uçta kalıntıları hala görülebilen bir duvarın bulunması bu alanın niteliği açısından son derece

1 Bu alanın hemen dışında kuzey yamaçlarında bulunan kanallardan evlenmek isteyen gençler dilekte bulunarak kayarlar (Lake, 1940, s. 182). Lake'in bahsettiği bu durum günümüzde de devam etmektedir.

2 Erken Hristiyanlık dönemi uzmanı ve filolog olan Lake'nin Hazine Kapısı/ Analıkız'daki çalışması Marr ve Orbeli'nin dokunmadığı bölümlerdeki son kalıntıların da ortadan kalkmasına neden olmuştur. Ayrıca Zimansky'nin belirttiği gibi Lake başka bir kaya nişinde değil (Zimansky, 2011, s. 63) Hazine Kapısı/ Analıkız'daki alanda çalışmıştır. 
önemlidir (Lake, 1940, s. 180-184; Korfmann, 1977, s. 182-185, Abb. Taf. VI-VIII)³. Lake bu alanda iki inşa evresinin bulunduğuna değinmektedir. İlk evrede ana kayaya açılan ve derinliği az olan yataklara iri taş blokların oturtulduğunu, ikinci evrede ise daha küçük taşların kullanıldığını belirtmektedir (Lake, 1940, s. 184).

\section{Alanın İşlevi ve Kronolojisi}

Bu durumda söz konusu veriler göz önünde bulundurularak alanın kimliği ile ilgili yeni bir yaklaşım geliştirilebilir. Duvarlarla çevrili ve kapalı biçimde, anıtsal nişlerin içinde stellerin yer aldığı bu alan tam olarak hangi dönemde ve ne tür etkiler sonucu inşa edilmişti? Batıdaki nişte II. Sarduri'nin kronikleri yer alırken doğudaki nişte hangi stel yer almaktaydı? Özellikle dört tarafinda yazıt bulunmasıyla dikkati çeken ve Surp Sahak Kilisesi’ndeyken kopyası alınan (Lehmann-Haupt, 1928-35, Taf. XXVI-XXIX, 112 A-B), I. Argişti'nin yıllıklarının kopyası durumundaki yazıtların ${ }^{4}$ yer aldığı stel bu alanda kullanılmış olabilir miydi? Öyle anlaşılıyor ki I. Argişti ile birlikte stellerin dört tarafına yazıtlar işlenmeye başlamıştır. Surp Sahak Kilisesi'ndeyken kopyası alınan bu stellerin boyutu, tasarımı ve özellikle nereye dikildiği günümüze kadar incelenmiş değildir. Van Sitadeli’nin kuzeydoğu yamaçlarında yer alan ve günümüzde Analıkız olarak bilinen bölümdeki iki nişten doğuda yer alan nişin, I. Argişti'nin yıllıklarının bulunduğu Surp Sahak stelleri için oluşturulmuş olduğu önerilebilir. Benzer şekilde Minua'nın Surp Boğos Kilisesi’nde bulunan stelinin Analıkız Alanı ile muhtemel bir ilişkisi olabilir miydi sorusu akla gelmektedir.

Analıkız alanında insitu bulunan II. Sarduri dönemine ait yazıtlı stelin üst bölümü daha önce de değindiğimiz üzere Surp Boğos Kilisesi’nde yapı malzemesi olarak kullanılmıştır. Batı nişin sol duvarında okunan Ermenice bir yazıt MS. 949 tarihini vermektedir (Marr ve Orbeli 1922, s. 18). Bu tarih aynı kilisenin inşa tarihi olabilecek olan kilisedeki MS.960 tarihini veren bir yazıt ile yakındır. Salvini Analıkız alanındaki bu stel parçalarının Surp Boğos Kilisesine taşınmasının aynı tarihler olabileceğini bildirir (Salvini, 2006, s. 74).

Marr-Orbeli kazı bilgileri ve görsellerine bakıldığında batı niş’te yer alan yazıtlı bazalt kaide üzerindeki stelin Urartu döneminde olduğu gibi in situ durmadığı not edilmelidir. Gerek stelin alt kısmında olması gereken stel ayağının eksikliği gerekse stel üzerindeki tahribatlar alana müdahalenin Ermenilerden önce belki de Urartu döneminde olduğunu göstermesi açısından önemlidir. Nitekim stel düşmüş veya düşürülmesi akabinde doğru bir tarzda yerine konulmaya çalışılmıştır.

3 Lake, batıdaki nişin karşısında yer alan yüksek platformu kurban kesim yeri olarak değerlendirmektedir (Lake, 1940, s. 182).

4 Bu stellerin içeriğinin I. Argişti yıllıklarının tam olarak kopyası olmadığı, bazı kısımların kopya olduğu ve bazılarınınsa paralel metinler olduğu belirtilmektedir (Salvini, 2006, s. 68). 
Surp Boğos Kilisesi'ne Analıkız da kullanılan stel parçalarının yapı malzemesi olarak götürülmüş olduğu göz önüne alındığında aynı kilisede yine yapı malzemesi olarak kullanılan Minua kronik yazıtının (CTU I: A 5-9) işlendiği stel parçasının da Analıkız alanından götürülmüş olabileceği göz önüne alınmalıdır (Resim 20). Bu durum bugün boş olan doğu (sol) nişin kronolojisi hakkında da bize kimi ipuçları verebilir. Minua yazıtının olduğu taş $140 \mathrm{~cm}$ genişliğinde, $61.5 \mathrm{~cm}$ yüksekliğinde ve mevcut durumda $46 \mathrm{~cm}$ derinliğinde büyük bir stel kaidesi olmalıdır. Nitekim kaidenin ön ve üst tarafında yazıt metni işlenmiştir. Üst yüzdeki yazıtın ortasına yakın bölümüne ise iç içe iki daire şeklinde bir sunu çanağı? oyulmuştur. Taşın yazısız olan arka yüzü büyük bir haç ve Ermenice kısa yazılarla işlenip taşın sonradan "Haçkar" olarak kullanıldığını göstermektedir. Bu kaide üst yüzüne oyulmuş sunu çanağ 1 ve yan yüzüne işlenmiş yazıtı ile yine Minua dönemine ait Gameşvan/Kamişvan (Patnos/Değirmendüzü) yazıtlı stel kaidesine çok benzemektedir (CTU I. A 5-70) (Resim 21) Bu durumda Surp Boğos Minua Kroniği yazıtının olduğu taşa önünde bir sunu çanağı? bulunan bir stel kaidesi demek daha doğru olacaktır. Eldeki bu verilerden hareketle Surp Boğos'da bulunan stel kaidesinin Analıkız alanında doğu nişinde kullanılmış olabileceği de ikinci bir varsayım olarak akılda tutulmalıdır.

Analıkız'ın yaklaşık 350 m. doğusunda Tebriz Kapı Yazıtı yer alır. Yazıt 3.10x1.45 metre ölçülerinde ve yaklaşık 5-10 cm derinliğinde dikine dörtgen bir çerçeve içine yerleştirilmiştir. 34 satır halinde çivi yazılı metin yer alır. İçerik açısından iki noktada büyük önem taşır. Öncelikle ortak krallık olarak adlandırılan İşpuini-Minua dönemi'ne tarihlenir. Tebriz Kapı yazıtı oğlu İnuşpua'dan bahsetmesi açısından Minua'ya daha yakın bir kronolojiye işaret eder. Diğer bir önemli nokta ise yazıtta "Tanrı Haldi'ye adanan susi tapınağı" ve "Tanrı Haldi Kapılarının” inşa edildiğinin ifade edilmesidir.

Yine Minua döneminde yapıldığı üzerindeki yazıtlardan anladığımız Minua taramanili’si (su kaynağı), Analıkız'ın yaklaşık $450 \mathrm{~m}$, Minua siršini'si (ahır?) ise yaklaşık $950 \mathrm{~m}$ batısında yine kalenin kuzey yamaçlarında inşa edilmiştir. Her üç yapı da Van Kalesi’ndeki diğer yapıların aksine kuzey yamaçlarına, ova düzeyinde yakın alanlara inşa edilmişlerdir. Minua dönemi yapılarının özellikle lokasyonları dikkate alındığında kalenin kuzeydoğu yamaçlarında yer aldığı anlaşılmaktadır (Konyar, 2018).

Alanın genel yapısal karakteri göz önüne alındığında, farklı kronolojik süreçlere yayılan bir gelişim süreciyle oluştuğu söylenebilir. Doğu nişi ve önündeki alan ile batı nişi ve önündeki alan yapısal özellikleriyle iki farklı kronolojiye işaret eder. İçindeki yazıtla -yukarıdaki öngörü bağlamında- birlikte değerlendirdiğimizde, öncelikle doğu nişi ve önündeki alanın düzenlendiği öne sürülebilir. $\mathrm{Bu}$ durumda alanın Minua zamanında kronikler için inşa edilmeye başlandığını önerebiliriz. Daha sonra özellikle I. Argişti ve II. Sarduri döneminde alan doğuya doğru genişletilmiş ve mevcut cephe geriye doğru kademelendirilerek batı nişi 
açılmıştır. Bu alanın topografik özelliklerinden dolayı niş önündeki platform kademelidir ve en öndeki alan batıya doğru daralarak uzanmaktadır (Resim 22).

Bu durumda I. Argişti’ye ait neden bir üçüncü kaya nişi olmadığı sorulabilir. I. Argişti'nin söz konusu nişi yapmak yerine Horhor Mezarı cephesine kroniklerini işlemekle yetindiği ileri sürülebilir. I. Argişti büyük bir ihtimalle babası Minua’nın kroniklerinin olduğu alana Horhor kroniklerinin dublikati niteliğindeki Surp Sahak bazalt stellerini koymuş olmalıdır. Gerek Minua gerekse I. Argiști'ye ait geriye kalan az sayıdaki kronik stellerinin devamı olan stellerde yine Ortaçağ' da aynı akıbete maruz kalmış olmalıdır. Hemen yakınında bulunan Eski Van şehrinde ileri de yapılacak çalışmalarda söz konusu yazıt bloklarının muhtemelen yapı taşı olarak kullanılmış olduğu görülecektir.

\section{Kurban Kanalı?}

Daha önce kurban kanalı olarak adlandırılan Analıkız alanının kuzeybatısında yer alan ana kayaya işlenmiş kanal 30 metre uzunluğundadır (Resim 18). Kanalın başlangıç noktasından itibaren zemindeki genişliği 20-25 cm iken bu genişlik kuzeye doğru orta kısımlarda $40 \mathrm{~cm}$ ve daha aşağıda 55 cm’ye ulaşmaktadır. Böylece kanalın genişliği 20 ile $55 \mathrm{~cm}$ arasındadır. Kanalın derinliği ise 50-70 cm arasında değişmektedir. Kanalın üst kısmındaki yani yüzeydeki genişliği 50 ile $60 \mathrm{~cm}$ arasında değişmektedir. Yüzeydeki bazı düzenlemeler kanalın üstten kısmen kapatılmış olduğunu göstermektedir. Bu kanal (Lehmann-Haupt, 1926, s. 30; Tarhan, 2011, s. 322) alanın kuzeyini çevrelemiş olabileceğini düşündüğümüz duvarların dışında kalmaktadır ve büyük olasılıkla drenaj kanalı olmalıdır ${ }^{5}$ Söz konusu kanalın bulunduğu yer ve konumu, derinlik, uzunluk ve genişliği sitadeldeki suların tahliyesi ile ilgili olduğunu göstermektedir. Ayrıca Hazine Kapısı/Analıkız'ın yaklaşık olarak 200 metre batısında ve doğu hendeğine doğru Osmanlı dönemi surlarının 20 metre kuzeyinde ana kayaya açılmış başka bir kanalda yüzeyde görülmektedir. Hazine Kapısı/Analıkız'a doğru batı-doğu hattında uzanan bu kanalın 12 metrelik bölümü ölçülebilmektedir. Genişliği $35-40 \mathrm{~cm}$ derinliği ise 40-60 cm civarında olan bu kanal da sitadelin drenaj kanallarından birini oluşturmaktadır.

\section{Alan Kapalı mıydı?}

Özellikle batı nişinin karşısında daha yüksekte oluşturulmuş kayalık platform üzerinde duvar yataklarının izleri görülmektedir (Resim 23). Bu alanın batısındaki kayalık ise tıraşlanmadan bırakılmıştır. Bu kayalık çıkıntının kuzeyinden itibaren drenaj kanalı başlamaktadır. Bu durumda bu kayalık çıkıntıyı da kapsayan bir duvarın varlığı dikkate değerdir. Yine alanın güneyini oluşturan her iki nişin üst kısmındaki kayalıkta yer alan duvar yatakları ile alanın doğ $\mathrm{u}^{6}$ ve batısındaki duvar yataklarını da göz önüne aldığımızda bu

5 Bu türden drenaj kanalları yine Van Kalesi’nin çeşitli bölümlerinde izlenebilmektedir.

6 Analıkız'ın doğusundaki temel yatakları 14x7 m 'lik bir alanı kaplamaktadır. Bu temel yatakları doğudaki nişin doğusundan itibaren başlamaktadır. 
alanın kapalı olabileceğini söyleyebiliriz. Ayrıca Van'ın iklimi, kar ve yağmur yağış oranları göz önünde bulundurulduğunda alanın içinde biriken suları tahliye edebilecek herhangi bir kanal ve giderin olmaması da Analıkız alanının üst kısmının kapalı olduğu tezini güçlendirmektedir. Özellikle aşağıdan basamak ve yol gibi herhangi bir ulaşımın olmaması ve bu alanda da kaya basamakları ve ana kaya işçiliğine dair diğer düzenlemeler de bu mekânın sitadelle ilişkisini güçlendirmektedir.

\section{Sonuç}

Hazine Kapısı ya da Analıkız olarak bilinen bu alan 19. yüzyıl boyunca hikayeci bir söylemle tanımlana gelmiştir. Bu hikaye bağlamında Layard'ın Analıkız'da yaptığı kazı aynı zamanda Urartu arkeolojisinin de ilk kazısını oluşturmaktadır. Marr-Orbeli ve sonrasında Lake'nin yaptığı kazı çalışmaları ise alanın anlaşılması açısından önemlidir. Ancak bu kazılar da alanın tamamen boşaltılması biçiminde devam ettiğinden bu anıtsal mekanın geçirdiği dönem ve evrelerin anlaşılmasını zorlaştırmaktadır. Lehmann-Haupt'un bu alanın kuzey yamaçlarından aşağıya doğru devam eden kanalı kurban kanalı olarak tanımlaması ise Analıkız'ın 1916 ve 1938 yıllarındaki kazılarla tamamen boşaltılması ile açık hava kutsal alanı veya tapınağı biçiminde tanımlanmasına dayanak oluşturmuştur. Ancak kazı sonuçları, alanın iç kısımlarından kaldırılan duvar kalıntıları ve günümüzde gözlemlediğimiz duvartemel yatakları gibi arkeolojik izler bu alanın açık olmadığını teyit etmektedir. Özellikle kurban kanalı olarak tanımlanan kanalın aslında sitadelin sularını ve atıklarını bir şekilde tahliye eden drenaj kanalı olduğu anlaşılmaktadır. Çevresindeki duvar yatakları gibi kalıntılar ve izler de bu alanın kapalı olduğuna işaret etmektedir. Alanın yapım evresi ve inşa aşaması ele alındığında ise başlangıçta Minua'nın Tebriz Kapı Kaya yazıtında işaret ettiği Haldi Kapıları somut olarak bu alana tekabül ediyor olabilir. Diğer taraftan I. Argişti ile başlayan stel geleneğinin II. Sarduri ile devam etmesi baba ve oğulun aynı geleneğin temsilcileri olarak bu alanda anıtsal nişleri devam ettirdikleri de söylenebilir. Bu bağlamda bu alandaki anıtsal yapılaşma krallığın geçirdiği değişimler çerçevesinde gelişerek devam etmiş ve sitadel içerisinde anıtsal nişler ve dikilitaşlarının bulunduğu önemli ve kralların yıllıklarını işledikleri bir hafıza merkezi olmuştur.

Finansal Destek: İstanbul Üniversitesi Bilimsel Araştırma Projeleri Birimi tarafından desteklenmiştir (Proje No: SBA-2019-34048) 


\section{Kaynakça}

Çilingiroğlu, A. (1998). Urartu'da tapınma ve tapınma yerleri. In G. Arsebük, M. J. Mellink, W. Schirmer (Ed.), Light on Top of the Black Hill: Studies presented to Halet Çambel kitabı içinde (s. 230-239). İstanbul: Ege Yayınları.

Çilingiroğlu, A. (2011). Urartu dini / Urartian religion. In K. Köroğlu, E. Konyar (Ed.), Urartu: doğuda değişim / transformation in the east kitabı içinde (s. 186-199). İstanbul: Yapı Kredi Yayınları.

Dinçol, A. M., \& Dinçol, B. (1986). Eine wiederentdeckte assyrische inschrift auf den Van-felsen. Anadolu Araştırmaları, 10, 351-358.

Erzen, A. (1978a). Çavuştepe I. M.Ö. 7.-6. yüzyıl Urartu mimarlı anıtları ve ortaçağ nekropolü. Ankara: Türk Tarih Kurumu.

Genç, B. (2015). Urartu ve Assur arasındaki kültürel ilişkiler ve Urartu'nun dönüşümünde Assur etkisi, (Doktora Tezi). Marmara Üniversitesi Sosyal Bilimler Enstitüsü, İstanbul.

Korfmann, M. (1977). Die ausgrabungen von Kirsopp und Silva Lake in den Jahren 1938 und 1939 am burgfelsen von Van (Tušpa) und in Kalecik. Berytus, Archaeological studies, 25, 173-200.

Kroll, S., Gruber, C., Hellwag, U., Roaf, M., \& Zimansky, P. (2012). Introduction: Biainili and Urartu. In S. Kroll, C. Gruber, U. Hellwag, M. Roaf, P. Zimansky (Eds.), Biainili-Urartu: The Proceedings of the Symposium Held in Munich 12-14 October 2007 / Tagungsbericht des Münchner Symposiums 12.-14. Oktober 2007 (pp. 1-38), Leuven: Peeters.

Lake, K. (1940). Van'da yapılan hafriyat, 1938. Türk Tarih, Arkeologya ve Etnografya Dergisi, 4, 179-191.

Layard, A. H. (1849). The monuments of Niniveh. London: John Murray.

Layard, A.H. (1853). Discoveries in the ruins of Nineveh and Babylon; with travels in Armenia, Kurdistan and the Desert. London and New York: John Murray and G. P. Putnam.

Lehmann-Haupt, C. F. (1906). Materialien zur älteren geschichte Armeniens und Mesopotamiens. Berlin: Weidmannsche Buchhandlung.

Lehmann-Haupt, C. F. (1926). Armenien Einst und Jetzt, II(1). Berlin: B. Behr's Verlag.

Lehmann-Haupt, C. F. (1928-35). Corpus inscriptionum chaldicarum. Berlin and Leipzig: Walter de Gruyter.

Marr, N. Y., \& Orbeli, I. A. (1922). Archeologiceskaja ekspedicija 1916 goda v Van. Raskopki dvuch nis na Vanskoj skale i nadpisi Sardura vtorogo iz raskopok zapadnoj nisi. St. Petersburg: Russkoe Archeologiöeskoe Obscestvo.

Özgüç, T. (1969). Altıntepe II: mezarlar, depo binası ve fildişi eserler. Ankara: Türk Tarih Kurumu.

Pecorella, P. E., \& Salvini, M. (1984). Tra lo Zagros e l'Urmia: Richerche storiche ed archeologiche nell'Azerbaigiano Iranico. Roma: Roma, Edizioni dell'Ateneo.

Salvini, M. (2006). Urartu tarihi ve kültürü, (B. Aksoy, Çev.). İstanbul: Arkeoloji ve Sanat Yayınları.

Salvini, M. (2008). Corpus dei testi Urartei. Le iscrizioni su pietra e roccia, Roma: CNR - Istituto di studi sulle civiltà dell'Egeo e del Vicino Oriente.

Schulz, F. É. (1840). Memoire: Sur le lac de Van et ses environs. Journal Asiatique, 9 (3), 257-323.

Tarhan, M. T. (2011). Başkent Tuşpa / The Capital City Tushpa. In K. Köroğlu, E. Konyar (Ed.), Urartu: Doğu'da Değişim / Transformation in the East kitabı içinde (286-333) İstanbul: Yap1 Kredi Yayınlar1.

Tarhan, T. M. (1994). Recent research at the Urartian capital Tushpa. Tel Aviv, 21(1), 22-57.

Zimansky, P. (2011). Unutulan ve tekrar hayata dönen bir krallık: Urartu çalışmaları ve literatürü / A kingdom revived from oblivion: Urartian studies and literature. In K. Köroğlu, E. Konyar (Eds.), Urartu: Doğu'da Değişim/ Transformation in the East içinde (s. 56-71). İstanbul: Yapı Kredi Yayınları. 


\section{RESIMLER}

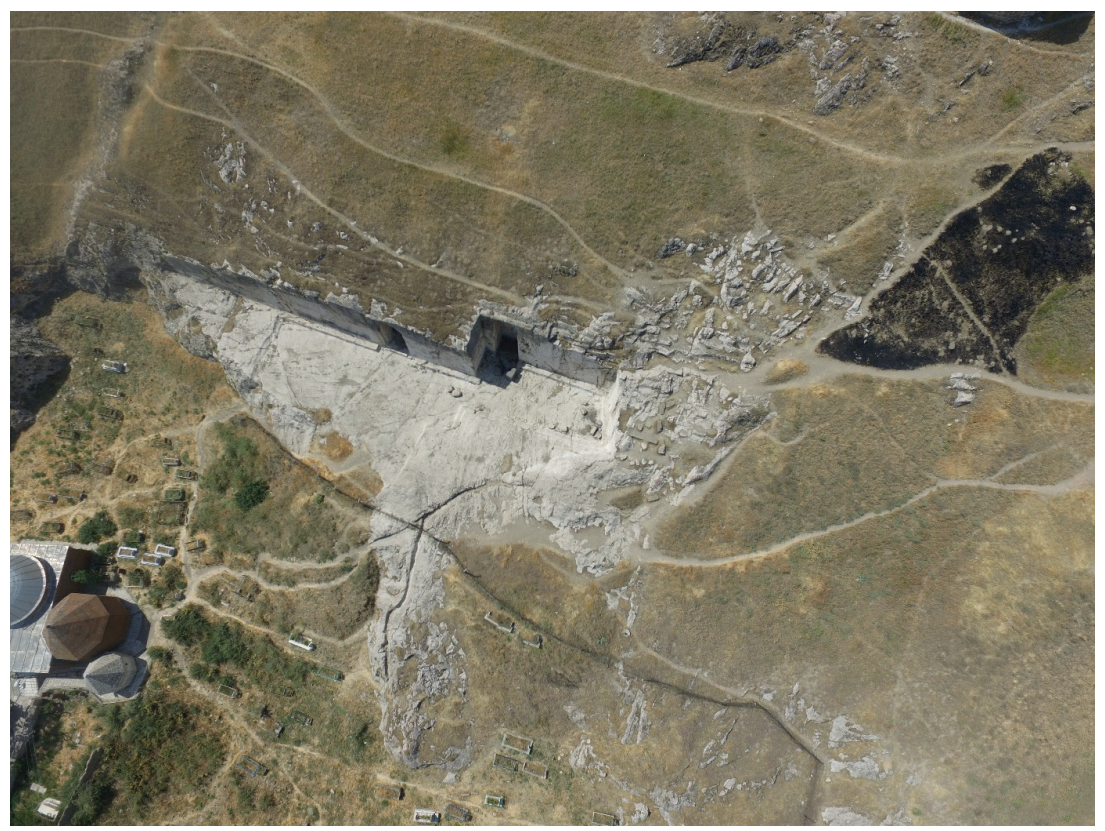

Resim 1. Analıkız Alanı ve Yakın Çevresi, Havadan.

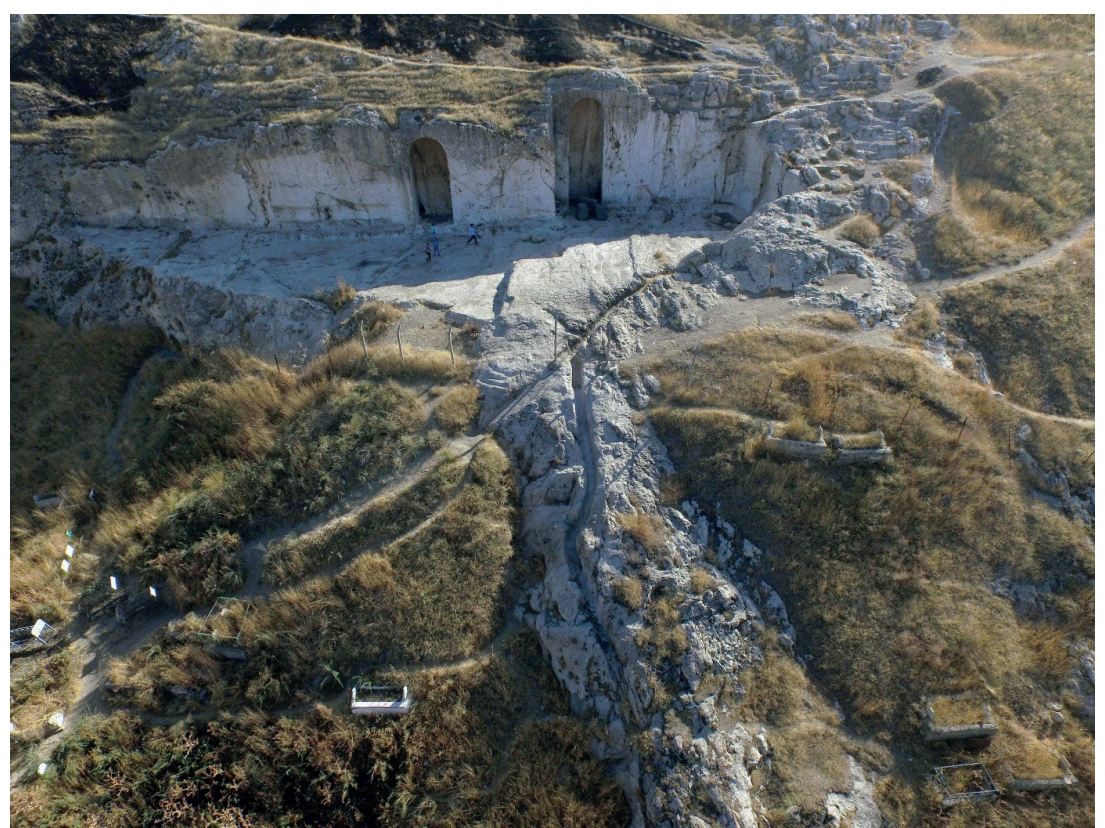

Resim 2. Analıkız Alanı Genel Görünüm, Kuzeyden. 


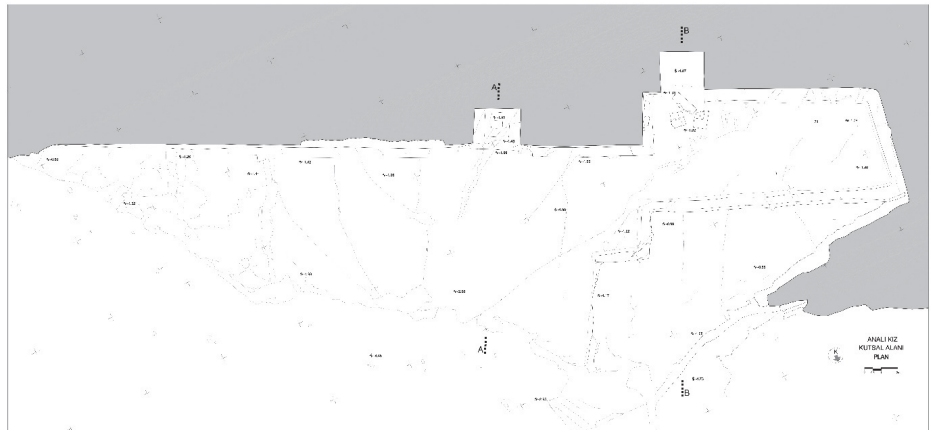

Resim 3. Analıkız Alanı Planı.

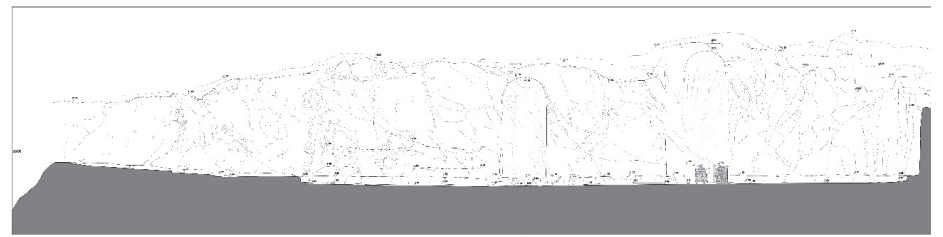

Resim 4. Analıkız Alanı Cephe Görünüşü.
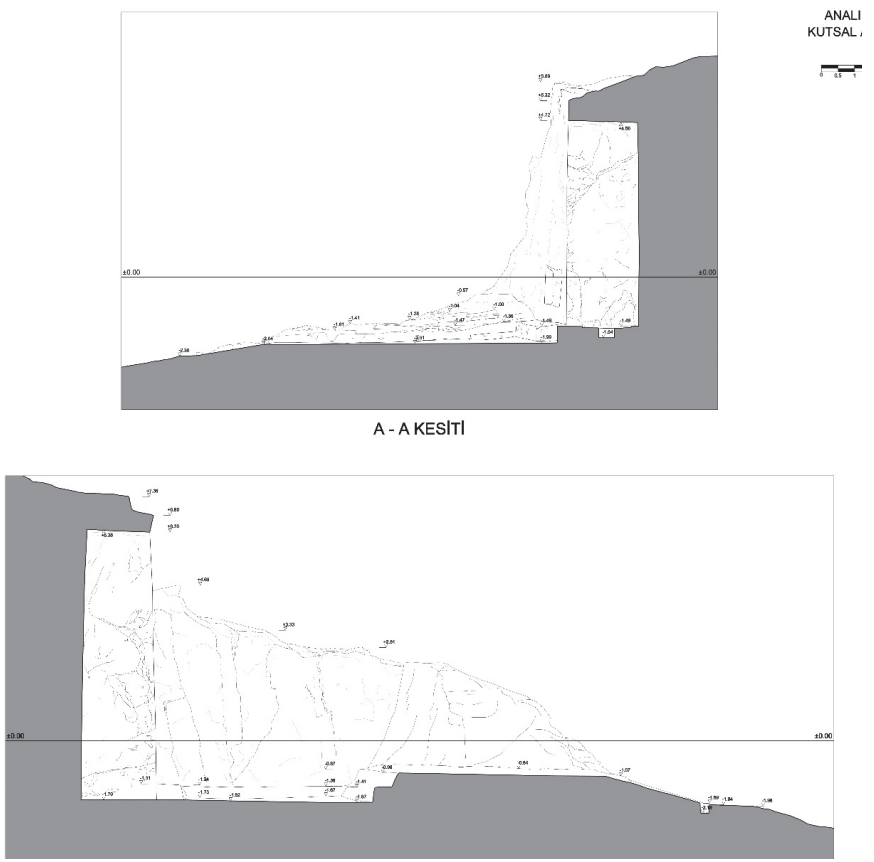

Resim 5. Analıkız Alanı Kesitleri. 


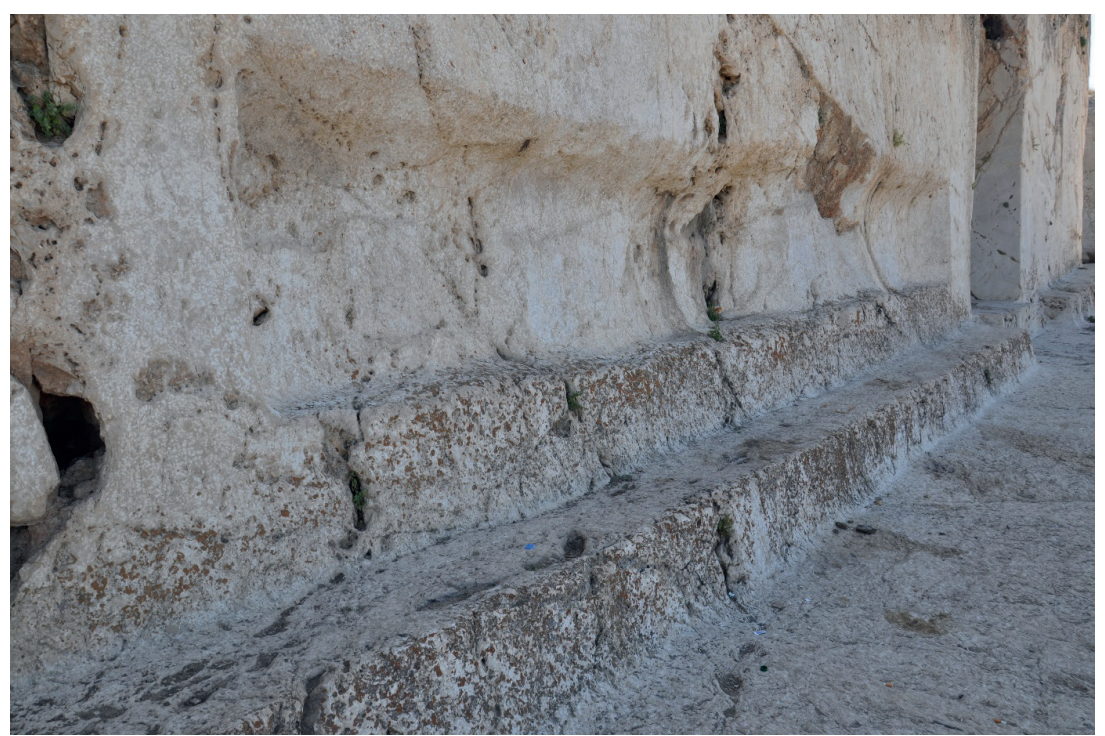

Resim 6. Analıkız Alanı, Doğu Nişin Solundaki Oyuk ve Sekiler.

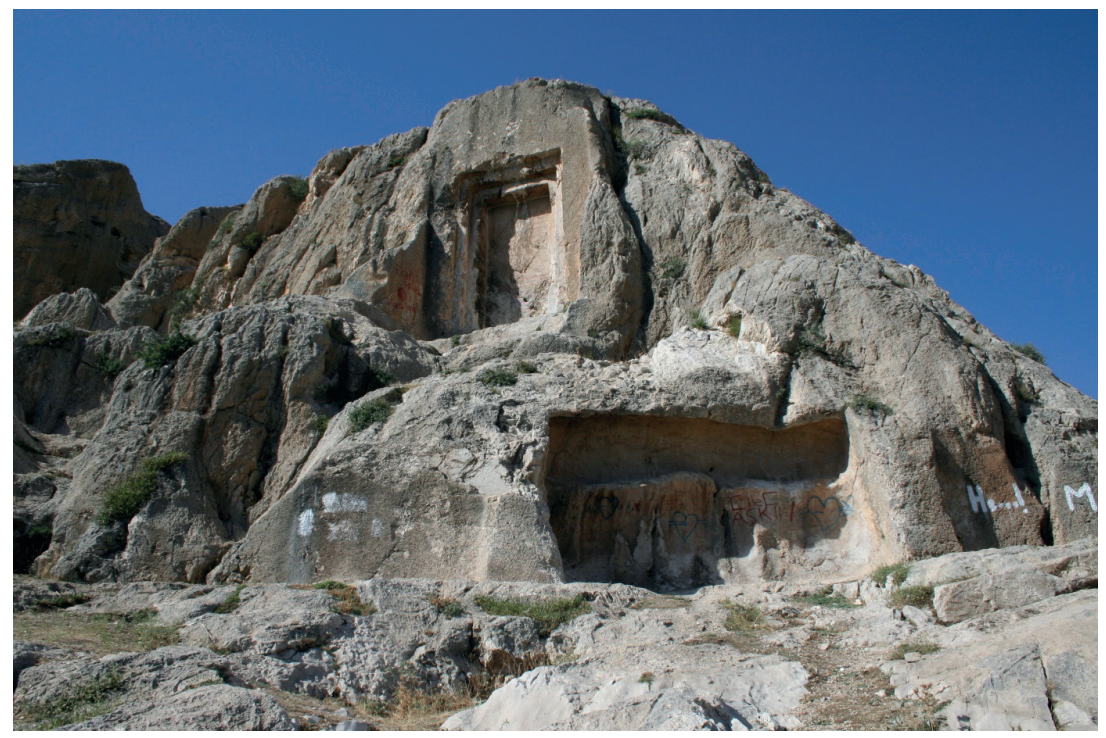

Resim 7. Meher Kapı Kaya Anıtı. 


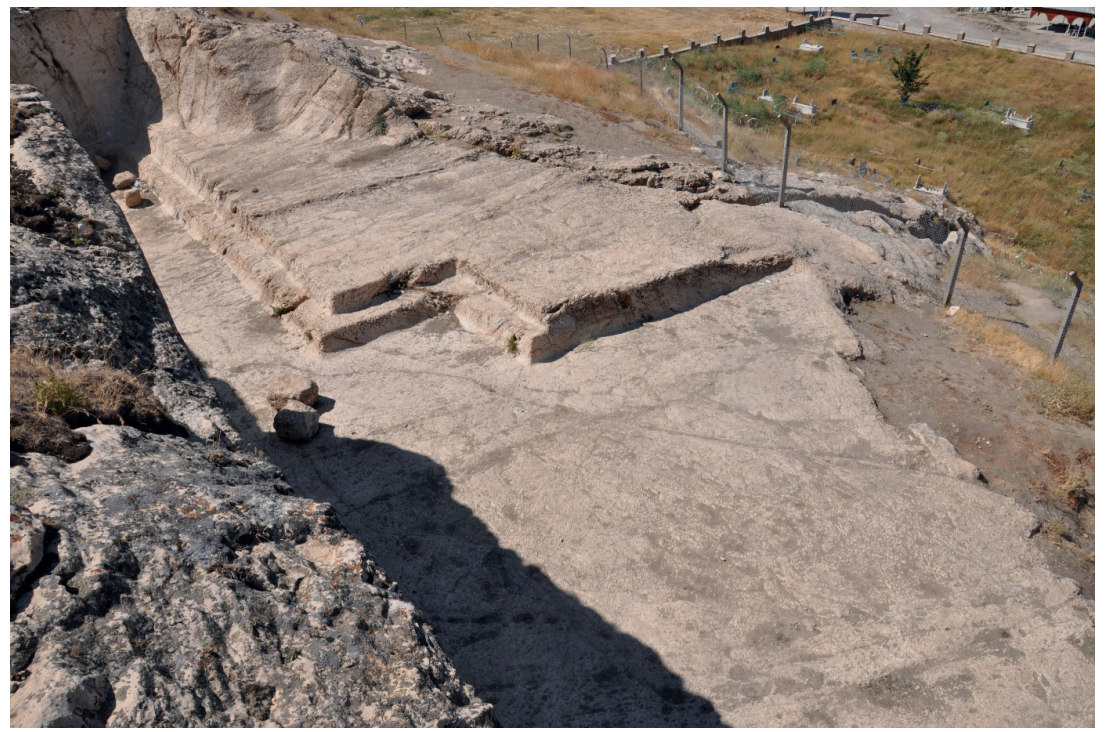

Resim 8. Analıkız Alanı Batı Niş Önündeki Platform ve Sekiler.

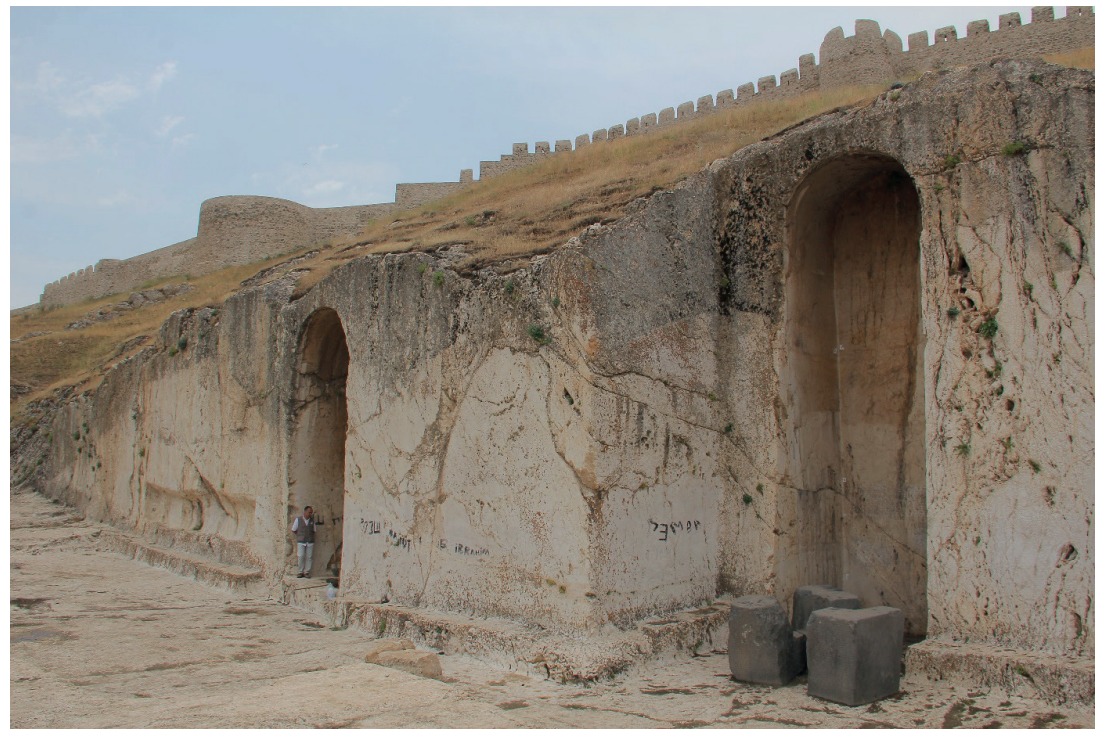

Resim 9. Analıkız Alanı Doğu ve Batı Nişler, Batıdan. 


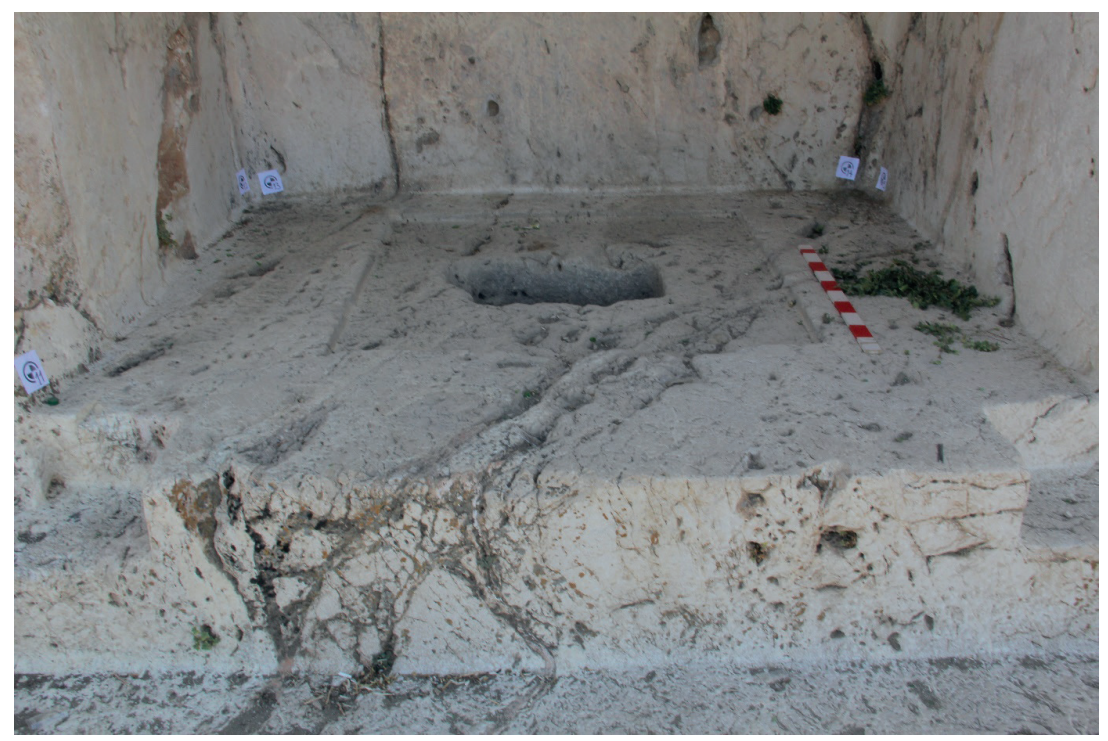

Resim 10. Analıkız Doğu Nişi Stel Yuvası.

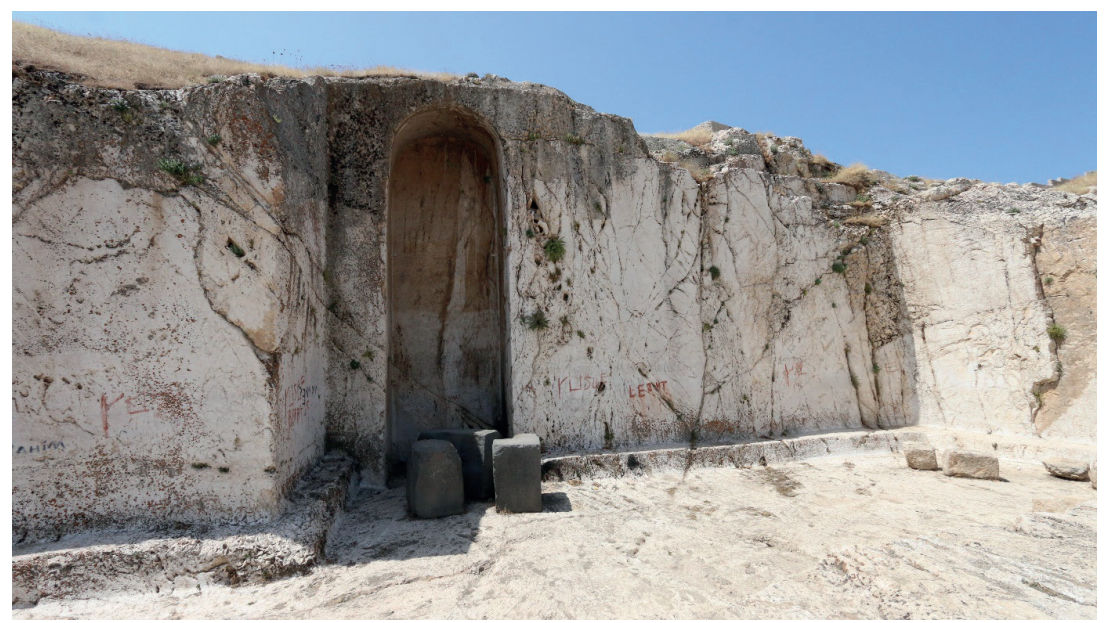

Resim 11. Analıkız Batı Nişi. 


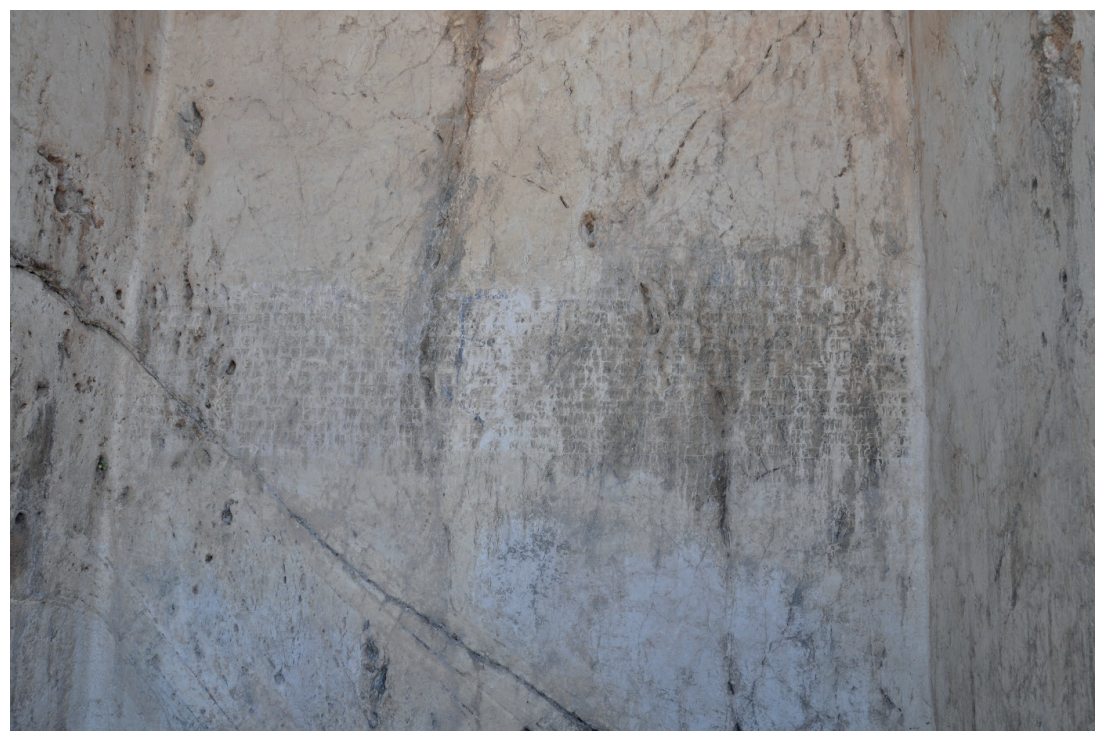

Resim 12. Analıkız Batı Nişinin, Ön Yüzündeki Çivi Yazısı.

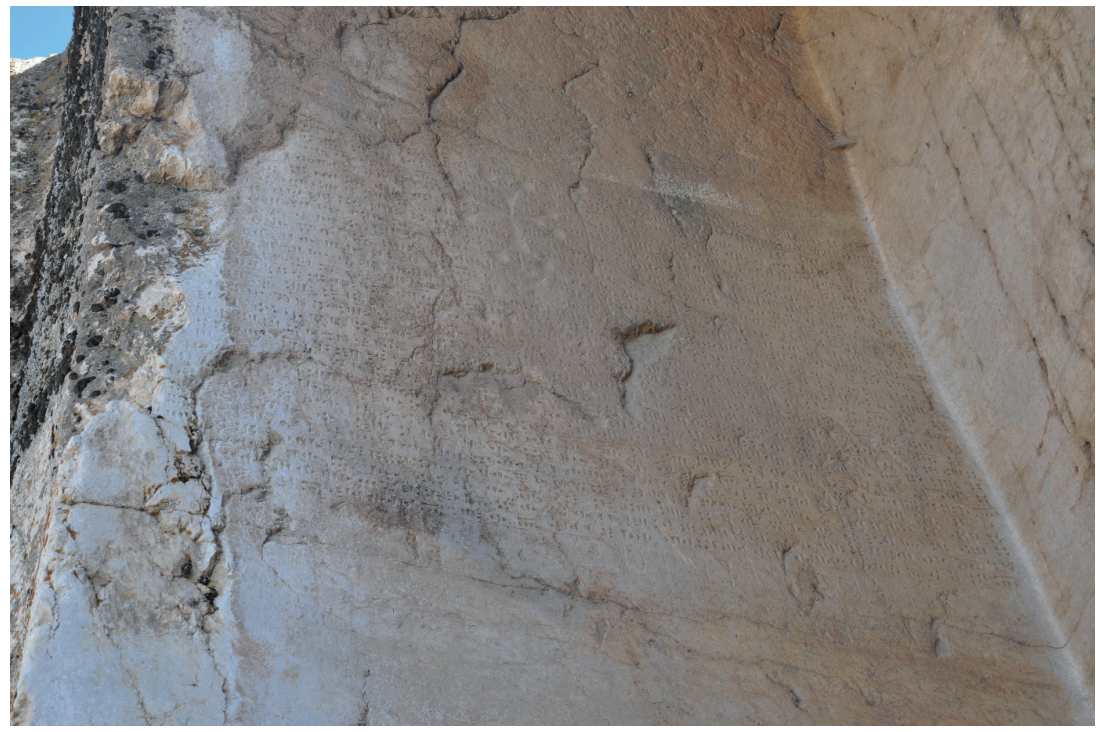

Resim 13. Analıkız Batı Nişinin, Doğu (Sol) Yüzdeki Çivi Yazısı. 


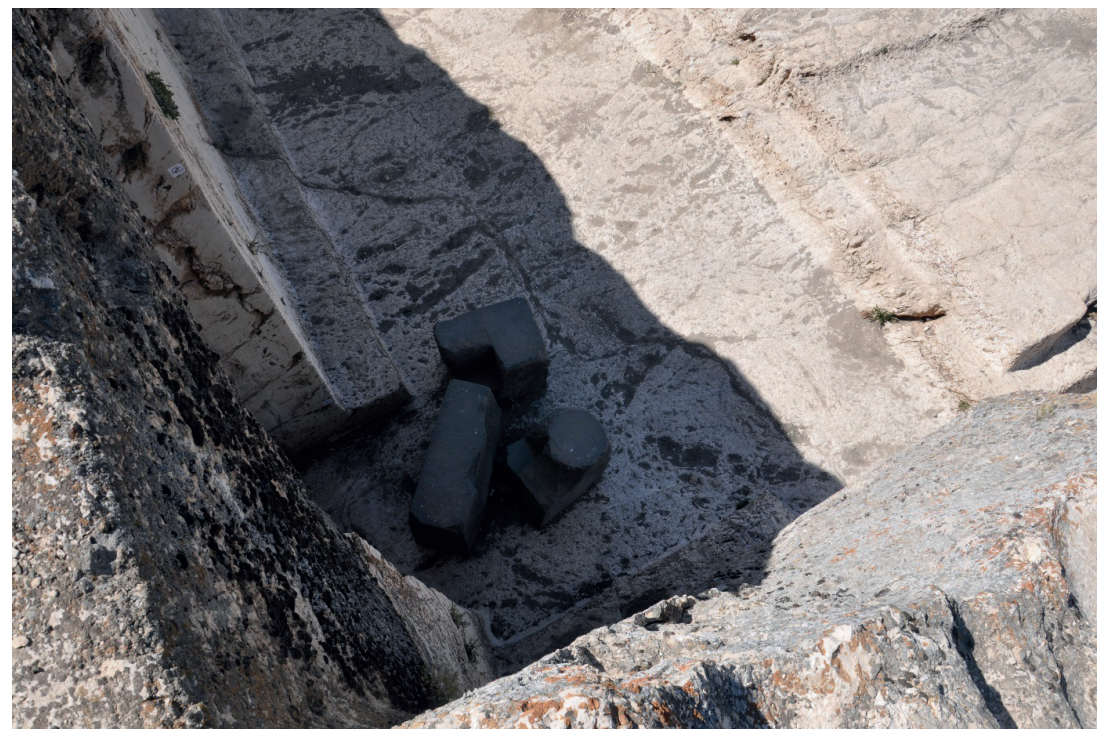

Resim 14. Analıkız Batı Niş Önündeki Stel Yuvalı Kaide.

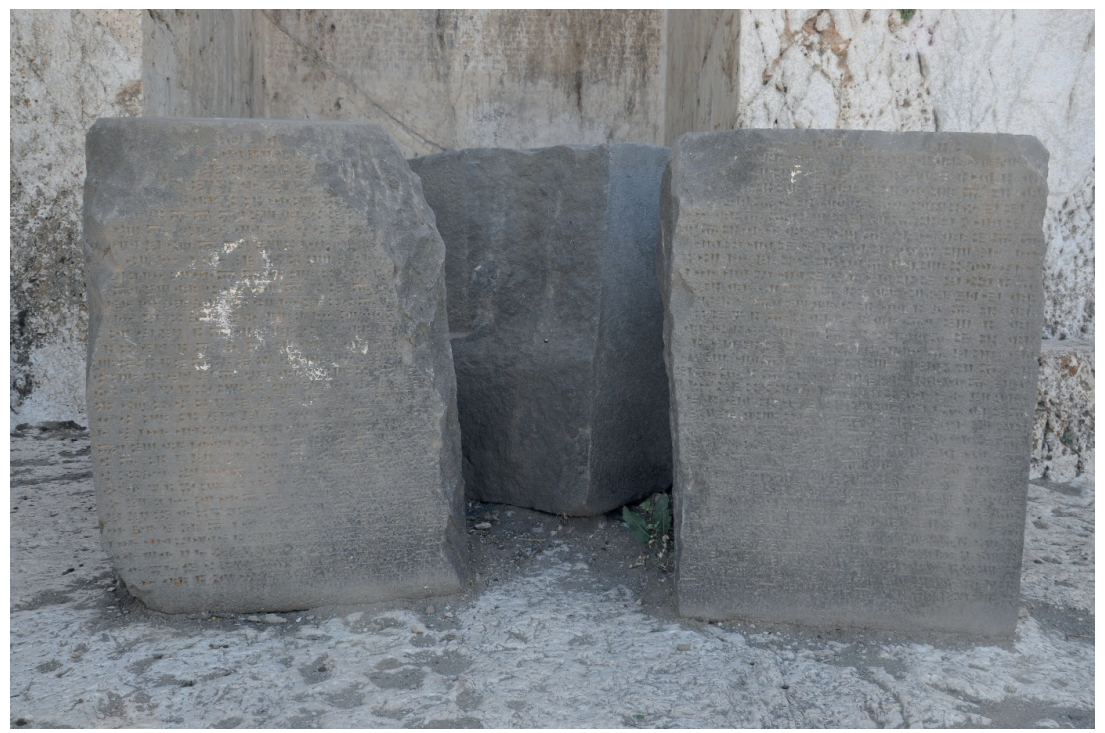

Resim 15. Analıkız Batı Niş Önündeki Stel Kaidesi Üzerindeki Yazıt. 


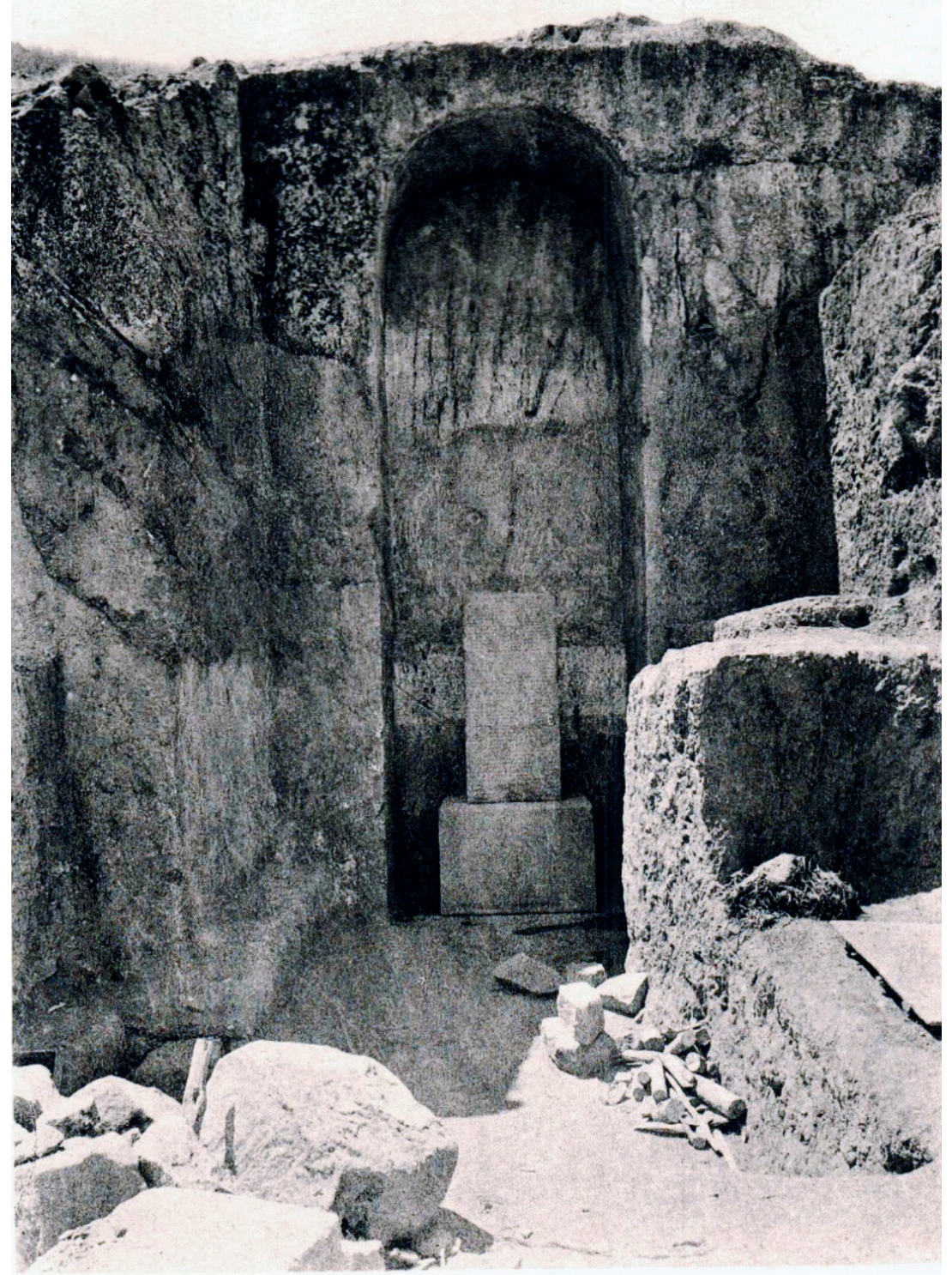

Resim 16. Analıkız Batı Nişi ve II. Sarduri Yıllıklarının Bulunduğu Stel ve Stel Kaidesi 1916 Yı1ında Yapılan Kazılar Sonucunda Ortaya Çıkarılmıştır (Marr - Orbeli 1922). 


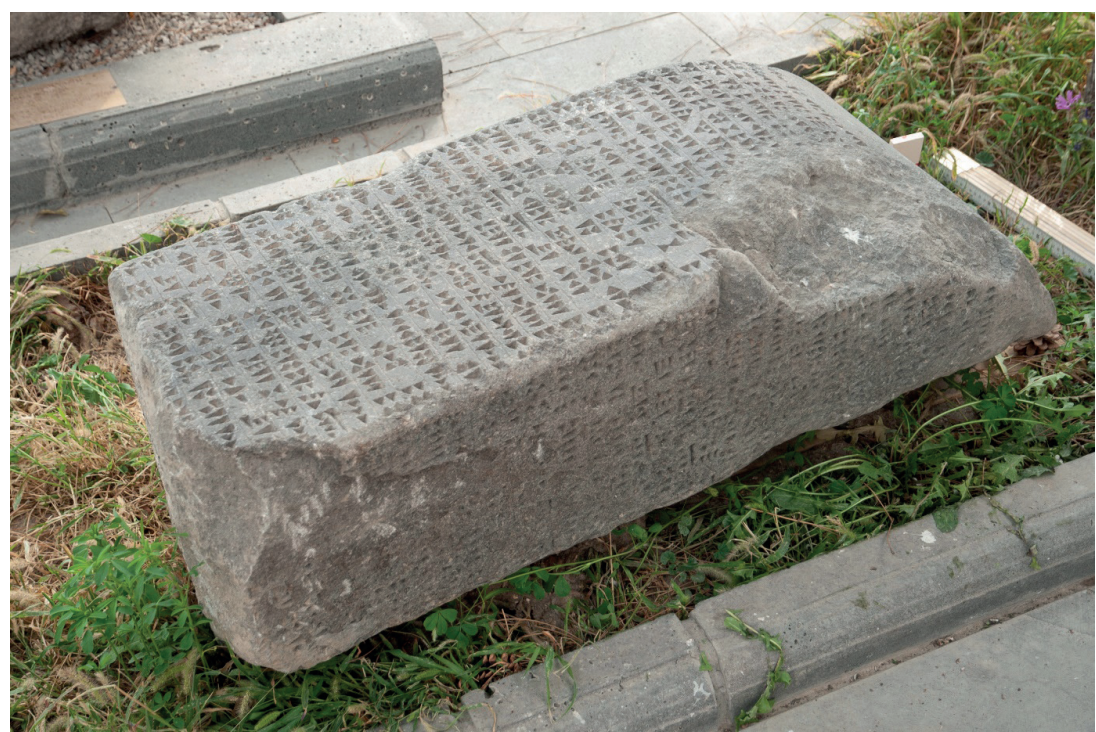

Resim 17. Surp Boğos Kilisesi’nde Yapı Malzemesi Olarak Kullanılan Stel Parçası Analıkız Batı Nişindeki Stelin Üst Kısmına Aittir.

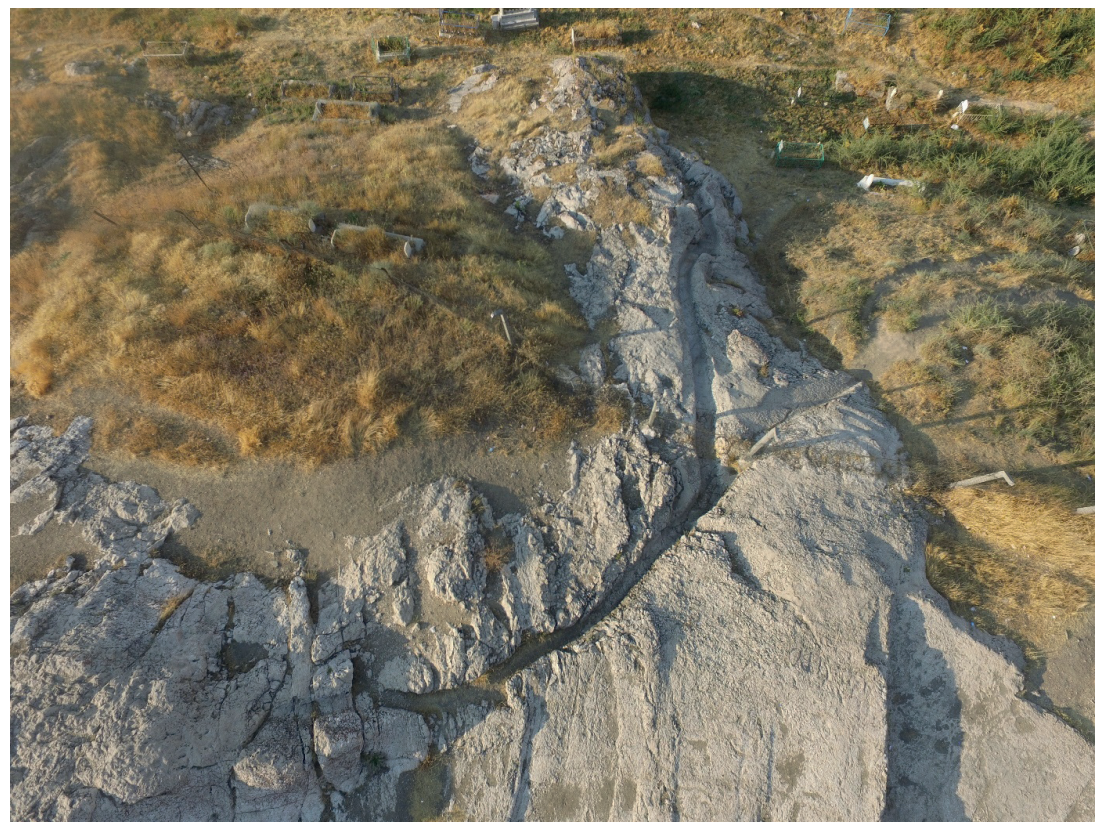

Resim 18. Analıkız Alanı’nın Kuzeyine Doğru Uzanan Kanal. 


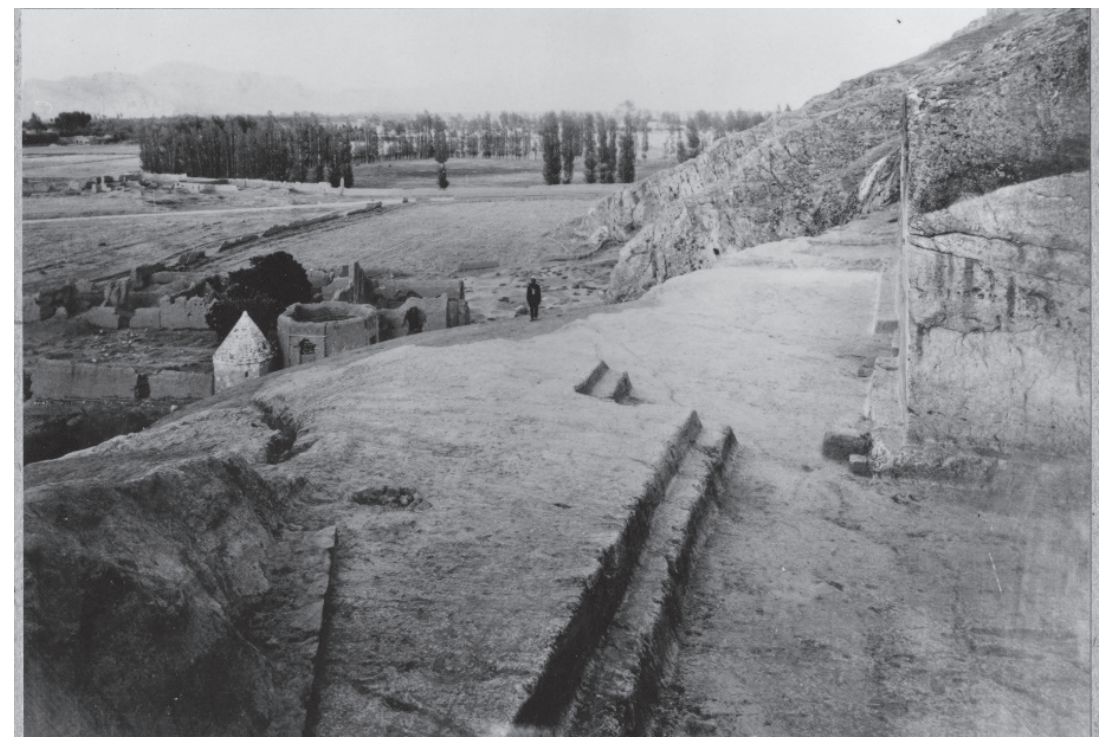

Resim 19. K. Lake'in 1938 Yılında Yaptığ Kazılardan Sonra Analıkız Alanı (Fotoğraf: D-DAI-IST-inv-43951).

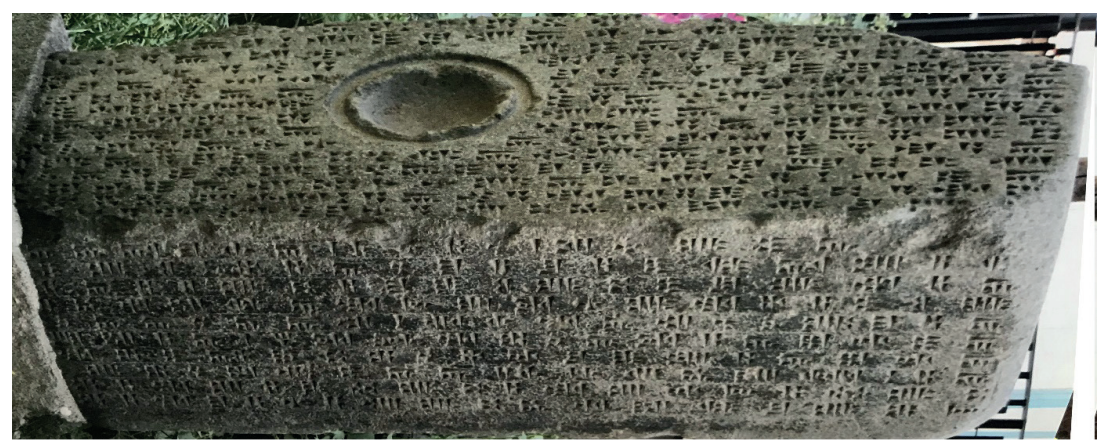

Resim 20. Surp Boğos Kilisesi’nde Yapı Malzemesi Olarak Kullanılan Minua Dönemi Stel Kaidesi. 


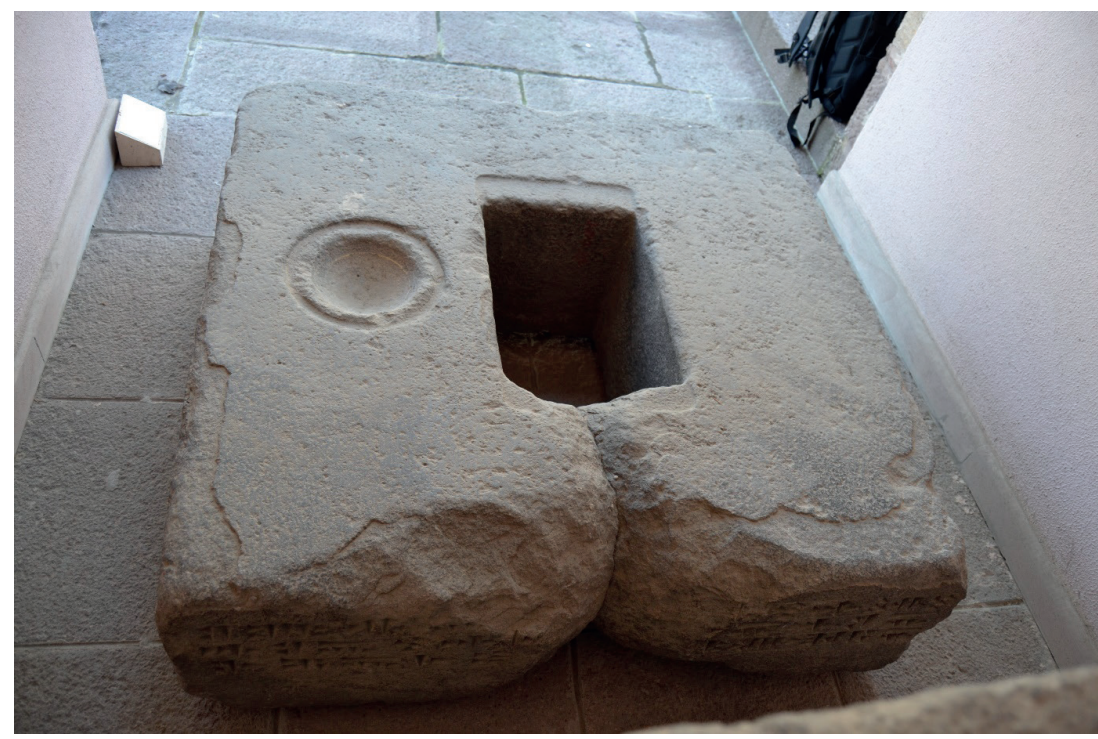

Resim 21. Minua Dönemine Ait Gameşvan/Kamişvan (Patnos/Değirmendüzü) Yazıtlı Stel Kaidesi.

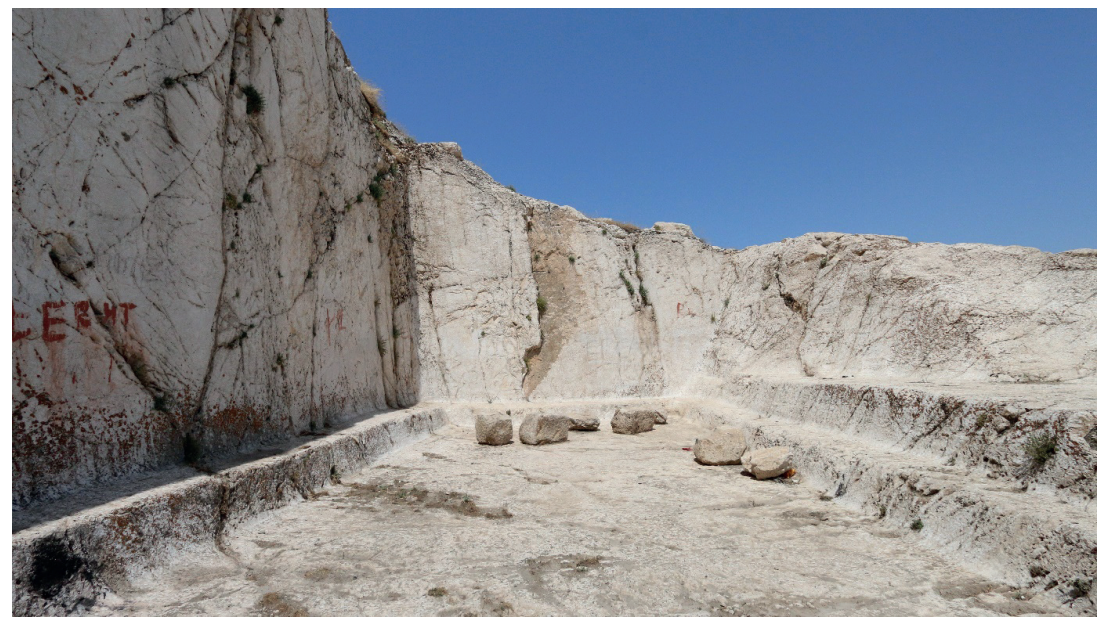

Resim 22. Analıkız Alanı Batı Niş Önü ve Batıya Doğru Uzanan Sekili Alan. 


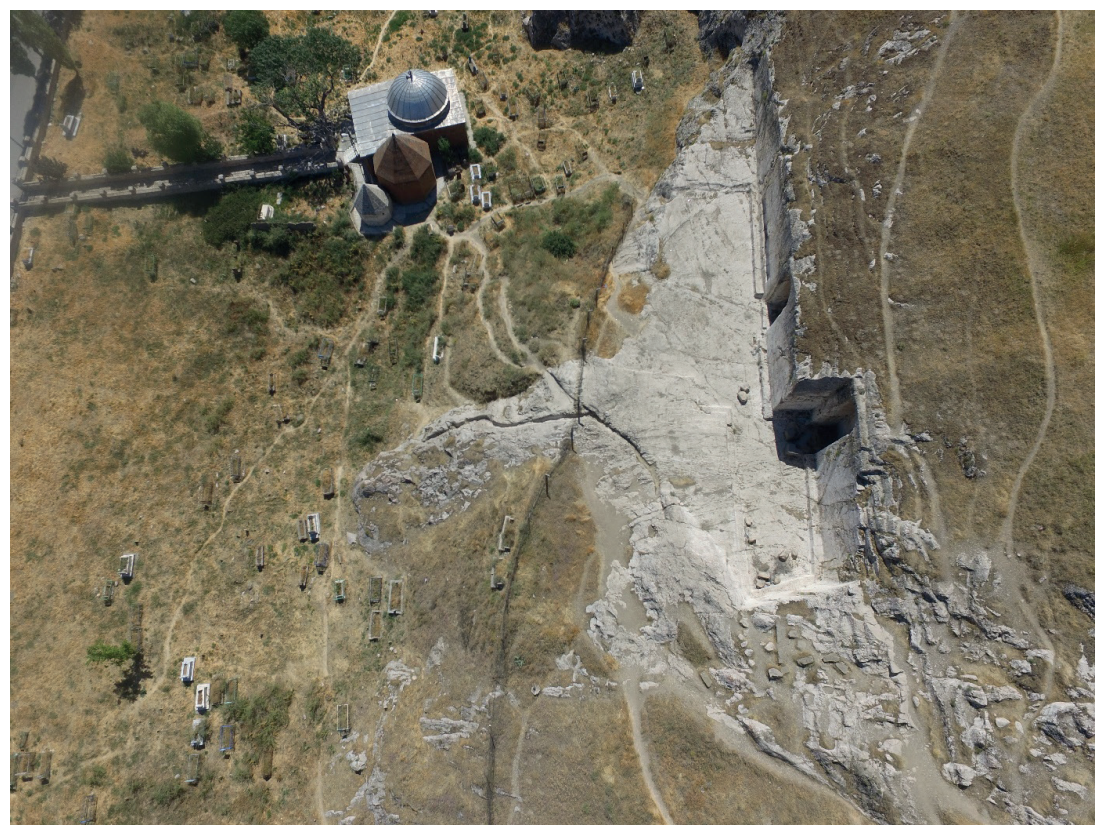

Resim 23. Analıkız Alanı'nın Kuzeyinde ve Batısında Yer Alan Temel Yatakları. 
